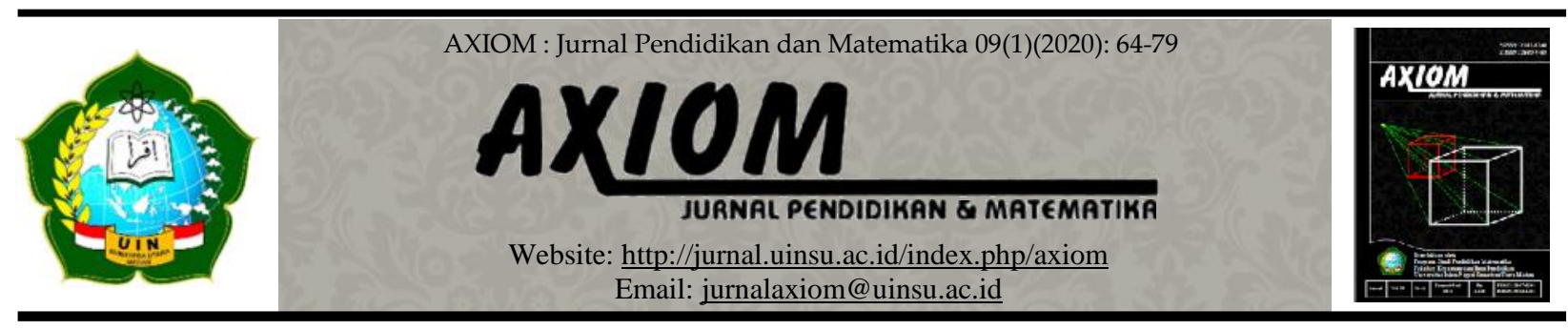

\title{
PENGEMBANGAN PERANGKAT PEMBELAJARAN DENGAN PENDEKATAN KNISLEY BERORIENTASI PADA LEVEL BERPIKIR VAN HIELE DAN KEMAMPUAN PENALARAN ADAPTIF
}

\author{
Oleh: \\ Heru Tri Novi Rizki ${ }^{1}$, Ariyadi Wijaya ${ }^{2}$, Diena Frentika ${ }^{3}$ \\ ${ }^{1}$ Pemanfaatan Sumberdaya Perikanan, Fakultas Pertanian, Universitas Cordova \\ ${ }^{2}$ Pendidikan Matematika, Pascasarjana, Universitas Negeri Yogyakarta \\ ${ }^{3}$ Teknik Pertambangan, Fakultas Teknik, Universitas Cordova \\ E-mail: ${ }^{1}$ heru.math.edu@gmail.com, ${ }^{2}$ a.wijaya@uny.ac.id, ${ }^{3}$ dienafrentika92@gmail.com
}

doi : 10.3082/axiom.v\%vi\%i.7237

\begin{abstract}
Abstrak:
Penelitian ini merupakan penelitian pengembangan perangkat pembelajaran geometri dengan pendekatan model pembelajaran matematika Knisley untuk meningkatkan level berpikir Van Hiele dan kemampuan penalaran adaptif siswa kelas VII SMP. Pengembangan perangkat pembelajaran ini didasarkan pada empat tahapan model pembelajaran matematika Knisley yang terdiri dari allegorization, integrator, analysis, dan synthesis. Penelitian ini menggunakan model pengembangan ADDIE. Instrumen penelitian yang digunakan adalah lembar validasi, lembar penilaian kepraktisan guru dan siswa, lembar observasi keterlaksanaan pembelajaran, tes level berpikir Van Hiele dan tes kemampuan penalaran adaptif. Perangkat pembelajaran dikatakan baik jika memenuhi aspek kevalidan, kepraktisan, dan keefektifan. Hasil penelitian menunjukkan bahwa perangkat pembelajaran memenuhi aspek kevalidan, kepraktisan, dan keefektifan dengan kriteria berikut 1) sangat valid menurut ahli dengan skor rerata 4,179 untuk RPP dan 4,230 untuk LKS, 2) sangat praktis menurut penilaian guru dengan skor rerata 5 untuk LKS dan RPP serta sangat praktis menurut penilaian siswa dengan skor rerata 4,538 untuk LKS, dan 3) sangat efektif berdasarkan level berpikir Van Hiele dengan banyaknya siswa pada level analisis mencapai 77\% dan berdasarkan kemampuan penalaran adaptif dengan ketercapaian persentase ketuntasan $64,71 \%$, rerata kelas 65,4 dan rerata skor 10,47 dengan kategori tinggi.
\end{abstract}

\section{Kata Kunci:}

Geometri, Kemampuan Penalaran Adaptif, Model Pembelajaran Matematika Knisley, Level Berpikir Van Hiele, Perangkat Pembelajaran

\section{Abstract:}

This study was a study of geometric instructional development with Knisley mathematics learning model approach to improved Van Hiele levels of thinking and adaptive reasoning skills of seventh' grade Junior High School students. The development of geometric instructional based on four phases of Knisley mathematics learning model were allegorization, integrator, analysis, and synthesis. This study used ADDIE's model. The research instrumens were validation sheets, teacher and student practicality assessment questionnaire, observation sheets for learning implementation Van Hiele levels of thinking tests and adaptive reasoning skills test. The instructional package is good if fulfilled validity, practicality, and 
effectiveness aspects. This study result showed that the instructional package fulfilled the following criteria: 1) very valid according to the average score of 4,179 for RPP and 4,230 for $L K S, 2)$ very practical according to the teacher's assessment with mean score of 5 for LKS and $R P P$ and very practical according to the assessment of students with an average score of 4,538 for LKS, and 3) very effective based on Van Hiele levels of thinking with the number of students at the analysis level reaching $77 \%$ and based on adaptive reasoning ability with completion of a classical was $64,71 \%$, average grade was 65,4 and average score was 10,47 with high category.

\section{Keywords:}

Geometric, Adaptive Reasoning Skills, Knisley Mathematics Learning Model, Van Hiele Levels Of Thinking, Instructional Package

\section{A. Pendahuluan}

Berdasarkan Peraturan Menteri Pendidikan Nasional No 22 Tahun 2006, salah satu tujuan pembelajaran matematika adalah agar siswa memiliki kemampuan menggunakan penalaran pada pola dan sifat, melakukan manipulasi matematika dalam membuat generalisasi, menyusun bukti atau menjelaskan gagasan dan pernyataan matematika sehingga penalaran menjadi aspek yang penting untuk dikembangkan. Hasil PISA (Litbang, 2010) dan TIMSS (Rosnawati, 2013: 2) yang masih menempatkan Indonesia pada kelompok bawah menunjukkan siswa Indonesia masih kesulitan menyelesaikan masalah tidak rutin sehingga penguasaan konsep matematis siswa masih pada ranah keterampilan dasar.

Hasil penelitian terdahulu juga menginformasikan masih rendahnya kemampuan penalaran siswa (Buhaerah, 2011; Subanindro, 2012). Menurut hasil penelitian Saputri, dkk (2017), salah satu penyebab rendahnya kemampuan penalaran matematika adalah kurangnya penguasaan dalam menemukan pola untuk membuat generalisasi. Padahal penalaran merupakan salah satu pilar utama pendidikan dalam proses learning to how (Zhou, 2005).

Untuk memiliki kemampuan penalaran yang baik, setidaknya siswa perlu menguasai kemampuan penalaran adaptif (KPA) karena KPA bagian dari kemampuan penalaran (Kilpatrick, dkk, 2001: 129). KPA diartikan sebagai lem yang menyatukan semua penalaran dan menjadi pedoman dalam belajar (Kilpatrick, dkk, 2001). Siswa dengan KPA yang baik dapat menggunakan logika untuk menjelaskan dan membenarkan solusi atas suatu masalah atau untuk memperluas pemahaman tentang hal yang belum diketahui menggunakan pengetahuan yang mereka miliki (Kilpatrick, dkk, 2001: 9). Selain itu, siswa juga mampu menentukan solusi dengan mengkategorikan benar atau salah dan mampu menjelaskan alasan secara logis mengapa hal tersebut benar/salah (Kilpatrick, dkk, 2001: 129).

Namun demikian peneliti terdahulu menemukan fakta masih rendahnya KPA siswa. Kilpatrick, skk (2001, 138-139) menemukan hanya 61\% siswa berusia 13 tahun yang benar dalam menyelesaikan masalah tentang penjumlahan bilangan bulat dan hanya $55 \%$ siswa yang benar dalam menyelesaikan masalah tentang pecahan. Dalam penelitian Ardiansyah (2012) juga menemukan fakta belum memuaskannya KPA siswa. Oleh karena itu untuk meningkatkan KPA siswa diperlukan inovasi pembelajaran matematika yang focus melatih kemampuan tersebut dilengkapi dengan perangkat pembelajaran yang mendukung.

Menurut hasil penelitian Aditya, dkk (2012), kemampuan penalaran matematis dapat ditingkatkan dengan Model Pembelajaran Matematika Knisley (MPMK). Model pembelajaran tersebut juga berpengaruh baik terhadap KPA (Mulyana, 2012: 1) karena sejalan dengan pandangan learning as understanding yang generatif, mendukung daya ingat, mengurangi yang harus diingat, meningkatkan transfer, dan mempengaruhi belief (Dedy, dkk, 2012: 107).

MPMK juga relevan untuk siswa di tingkat SMP sebagaimana teori Piaget. Peralihan berpikir dari ranah konkret ke formal sebagaimana teori tersebut relevan dengan 2 tahap awal MPMK yang memfasilitasi cara berpikir pada level konkret dan 2 tahap selanjutnya yang dirancang untuk memfasilitasi cara berpikir level abstrak (Knisley, 2003). Keempat tahapan belajar tersebut yaitu allegorization, intregator, analysis, dan synthesis (Knisley, 2003). 
Heru Tri Novi Rizki, Ariyadi Wijaya, \& Diena Frentika: Pengembangan Perangkat Pembelajaran dengan Pendekatan Knisley Berorientasi pada Level Berpikir Van Hiele dan Kemampuan Penalaran Adaptif

Sejalan dengan MPMK yang memfasilitasi belajar dari tahap konkret menuju abstrak, materi geometri merupakan salah satu materi yang cenderung lebih mudah dijelaskan dengan melibatkan hal-hal konkret yang berkaitan. Namun demikian hasil ujian nasional tahun ajaran 2015/2016 masih menunjukkan kurangnya penguasaan geometri dan pengukuran siswa Indonesia (BSNP, 2016). Bahkan materi geometri tergolong sulit bagi siswa dengan kesalahan yang paling banyak dilakukan adalah kesalahan pada proses (Jaya \& Kumaidi, 2014: 181). Padahal geometri memberikan peluang untuk membuat siswa berpikir secara aktif, melakukan senam otak dan mengembangkan keterampilan dalam menyelesaikan masalah, membuat perbandingan, dan membuat generalisasi (Bal, 2011: 97).

Menurut Sugiyarti (2013), siswa SMP masih kesulitan membedakan bangun datar karena pengaruh penyajian materi dalam buku yang belum mengoptimalkan kemampuan berpikir geometri. Kemampuan tersebut dapat dioptimalkan jika siswa memiliki level berpikir Van Hiele (LBVH) yang baik (Ural, 2016; Usiskin, 1982; Musa, 2016; Sugiyarti, 2013). Hal ini karena LBVH merupakan proses hirarki yang berstruktur tentang pemahaman geometris (Poh dan Leong, 2015). LBVH terdiri dari 5 level yaitu visualisasi, analisis, order, deduksi, dan rigor (Yazdani, 2007; Ural, 2016).

Hasil penelitian Musa (2016: 104) terhadap 4 siswa SMP mengungkapkan 50\% siswa berada pada level order tapi kurang memahami hubungan antar bangun untuk mengkonstruksi definisi sedangkan 50\% siswa lainnya masih pada level analisis. Sumber kesalahan geometri yang mendasar adalah ketidakmampuan siswa dalam menentukan bangun geometri karena kebiasaan dalam menentukan hanya berdasarkan pengamatan pada gambar dan belum berpikir geometri tentang suatu bangun serta belum dikuasainya logika dalam mengurutkan bangun gemoteri tersebut (Ural, 2016). Oleh karena itu diperlukan upaya pembelajaran untuk memfasilitasi LBVH agar siswa memiliki kemampuan berpikir geometri yang baik. Hal ini karena geometri merupakan jaringan interkoneksi yang membutuhkan representasi dan penalaran sehingga konseptualisasi dan analisis tidak hanya sebatas tampilan fisik namun sampai pada membayangkan secara spasial (Alex dan Mammen, 2012: 123).

Sebagaimana KPA, MPMK juga mampu meningkatkan LBVH secara efektif (Kurniawati, 2012). Untuk mengoptimalkan hasil diperlukan perangkat pembelajaran yang relevan. Oleh karena itu perlu pengembangan perangkat pembelajaran dengan pendekatan MPMK guna memfasilitasi KPA dan LBVH.

\section{B. Kajian Teoritis}

Adapun kajian teoritis yang digunakan dalam penelitian ini adalah sebagai berikut.

\section{Pembelajaran Matematika}

Belajar merupakan proses aktif siswa dalam mengkonstruksi hubungan yang bermakna antara pengetahuan baru yang dipelajari dengan pengetahuan yang telah dimiliki dalam interaksinya dengan lingkungan (Kemp, dkk, 1998: 120). Suatu pembelajaran dipandang sebagai proses aktif dalam menghubungkan konsep baru dengan konsep yang dimiliki, membuat koneksi antara pengetahuan yang lalu, sekarang, dan masa depan, serta suatu proses yang dipengaruhi oleh bagaimana pembelajaran itu dilakukan dan efektif tidaknya pembelajaran tersebut (Watkins, dkk, 2000: 91). Sementara itu menurut Orlich, dkk (2010: 11), matematika merupakan aktivitas memecahkan masalah. Karakteristik masalah yang dapat dipilih sebagai masalah matematika adalah a) untuk memberikan contoh umum, b) untuk menghasilkan diskusi, bukti dan justifikasi, dan c) untuk membantu siswa membuat hubungan antar topik. Hal ini karena belajar matematika lebih bermakna jika siswa mengkonstruksi pengetahuannya, bukan sekedar diberikan oleh guru matematika (Kennedy, dkk 2008: 55).

\section{Kemampuan Penalaran Adaptif}

Menurut Kilpatrick, dkk (2001: 129), KPA merupakan kemampuan penalaran yang lebih luas dan tidak hanya meliputi penjelasan informal dan pembenaran, tetapi juga penalaran intuitif dan induktif yang didasarkan pada pola, analogi, dan metafora. Perpaduan KPA dan penalaran 
metakognisi memungkinkan siswa mampu menggambarkan fenomena dari berpikir tingkat lanjut, refleksi, dan penjelasan kepada diri sendiri maupun orang lain (Donovan dan Bransford, 2005: 218). KPA merupakan kemampuan berpikir logis tentang hubungan antar konsep dan situasi, kemampuan untuk berpikir logis, kemampuan untuk berpikir reflektif, kemampuan untuk menjelaskan dan kemampuan untuk memberikan pembenaran (Widjajanti, 2011: 3; Ostler, 2011: 17; Dedy, dkk, 2012: 105). Hal ini sebagaimana pernyataan Kilpatrick, dkk (2001: 5) yang mendefinisikan KPA sebagai "capacity for logical thought, reflection, explanation, and justification”.

\section{Level Berpikir Van Hiele}

Teori LBVH digunakan untuk menjelaskan alasan mengapa banyak siswa mengalami kesulitan dalam geometri dan apa yang dapat dilakukan untuk mengatasi hal tersebut (Usiskin, 1982: 1). Menurut Poh dan Leong (2015: 501), teori LBVH merupakan proses hirarki structural tentang pemahaman geometris. Struktur hirarki tersebut menjelaskan cara berpikir dan jenis gagasan geometri yang berhasil dicapai sehingga tidak hanya sekedar menjelaskan seberapa banyaknya informasi yang diperoleh seseorang (Ural, 2016: 13). Van de Walle, dkk (2010: 400404), Yazdani (2007: 41), Crowley (1987: 1), Yin (2003: 71) dan Ural (2016: 13-14) menjelaskan bahwa LBVH terdiri dari 5 tahap yaitu level 0 (visualisasi), level 1 (analisis), level 2 (deduksi informal/order), level 3 (deduksi), dan level 4 (rigor). Umumnya, siswa SMP masih pada level 0 dan 1, namun untuk memudahkan belajar geometri dijenjang SMA maka siswa SMP perlu mencapai level analisis (Usiskin, 1982; Crowley, 1987: 6).

a. Visualisasi

Pada tahap visualisasi, siswa baru mengenal bentuk dari bangun-bangun geometri (Yazdani, 2007: 41). Siswa hanya mampu mengidentifikasi bangun geometri berdasarkan nama dan tampilannya serta belum mengenal sifat-sifat bangun geometri (Ural, 2016: 13; Van de Walle, dkk, 2010: 401). Hal ini karena siswa baru sebatas mempelajari kosakata geometri, mengidentifikasi bangun, memberikan gambar yang sesuai dan menggambarkan kembali bangun (Crowley, 1987: 2) sehingga siswa hanya fokus pada aktivitas memandang tampilan bangun dan belum membahas karakteristik bangun (Abdussakir, 2009: 4).

b. Analisis

Pada tahap analisis, siswa sudah mendapatkan konsep sifat bangun datar (Burger dan Shaughnessy, 1986: 31), namun belum mampu melihat hubungan antara beberapa bangun datar berbeda (Abdussakir, 2009: 4; Crowley, 1987: 2; Mayberry, 1983: 59).

c. Order

Pada tahap order, siswa sudah mengerti hubungan antar sifat bangun datar maupun pada beberapa bangun datar berbeda (Mayberry, 1983: 59). Siswa tidak lagi melihat bangun geometri saling terpisah namun sudah mulai mengenali sifat-sifat bangun berasal dari sifat bangun geometri lainnya (Alex dan Mammen, 2012: 124) sehingga siswa mulai dapat menjelaskan beberapa bangun geometri secara hirarki (Abu dan Abidin, 2013: 17).

d. Deduksi

Pada tahap deduksi, siswa sudah mulai mampu menjelaskan bangun geometri dengan mengembangkan bukti daripada sekedar hafalan (Alex dan Mammen, 2012: 124). Meskipun belum dapat menuliskan bukti secara deduktif, pada tahap ini siswa telah mengetahui langkah-langkah dalam pembuktian yang dibutuhkan (Mayberry, 1983: 59) namun kemampuan penggunaan sistem aksiomatis dan metode logis masih terbatas sehingga belum sebaik level rigor (Yazdani, 2007: 41).

e. Rigor

Pada tahap rigor, siswa telah dapat menggunakan berbagai sistem aksiomatik ataupun membandingkan beberapa sistem pembuktian (Crowley, 1987: 3). Oleh karena itu tahap ini disebut juga sebagai tahap berpikir sistem aksimatik deduktif untuk geometri (Van de Walle, Karp, dan Bay-Williams, 2010: 404) dengan kemampuan siswa untuk berpikir 
Heru Tri Novi Rizki, Ariyadi Wijaya, \& Diena Frentika: Pengembangan Perangkat Pembelajaran dengan Pendekatan Knisley Berorientasi pada Level Berpikir Van Hiele dan Kemampuan Penalaran Adaptif

matematis menggunakan penalaran deduktif (Abu dan Abidin, 2013: 17).

\section{Model Pembelajaran Matematika Knisley}

MPMK merupakan pengembangan dari model pembelajaran Kolb yang mengadopsi gaya-gaya belajar dalam teori experiential learning (Knisley, 2003: 2). Fokus utama model pembelajaran matematika Knisley adalah pada kegiatan awal yang mampu meningkatkan antusiasme siswa sehingga termotivasi untuk mengikuti pembelajaran (Knisley, 2003: 1). Motivasi tersebut akan memudahkan siswa mencapai tujuan pembelajaran karena mempengaruhi proses pengambilan keputusan, arah belajar, fokus belajar, dan tingkat usaha siswa selama pembelajaran (Lucas, dkk, 2010: 3). Adapun gaya belajar Kolb dan interpretasi Knisley dijelaskan sebagai berikut.

Tabel 1. Relevansi Model Pembelajaran Kolb dan Knisley

\begin{tabular}{ccc}
\hline No & Gaya Belajar Kolb & Gaya Belajar Matematika Knisley \\
\hline 1 & Concrete, Reflective & Allegorizer \\
2 & Concrete, Active & Integrator \\
3 & Abstract, Reflective & Analyzer \\
4 & Abstract, Active & Synthesizer \\
\hline
\end{tabular}

Gaya belajar tersebut menjadi tahap belajar matematika dengan penjelasan berikut.

a. Allegorization (Alegori)

Tahap allegorization guru menjelaskan konsep baru menggunakan konteks yang tidak asing atau sudah dikenal dan siswa masih belum mampu membedakan konsep baru dengan konsep-konsep yang telah diketahuinya tersebut (Knisley, 2003: 3). Pada tahap ini guru mendeskripsikan konsep baru ke dalam konteks yang telah diketahui secara intuitif sebagai pengantar ide baru dan usaha untuk membandingkan serta mengkontraskan ide baru dengan ide yang telah dimiliki (Knisley, 2003: 4). Dengan kata lain berlaku learning from experience sehingga aktivitas belajar akan terhubung langsung dengan pengalaman siswa (Muijs, 2010: 861). Oleh karena itu, experience based learning penting diterapkan dalam mengajarkan konsep kepada siswa (Kolb, 2015: x). Berdasarkan penjelasan tersebut, tahap allegorization dalam penelitian ini berbentuk kegiatan "Ayo Mengingat" untuk memberikan kesempatan siswa mengingat pengetahuan yang dimiliki.

b. Integration (Integrasi)

Tahap integration merupakan tahap belajar siswa untuk melakukan perbandingan, pengukuran, dan eksplorasi untuk membedakan konsep baru dengan konsep yang diketahui (Knisley, 2003: 3). Kunci utama tahap ini adalah visualisasi, eksperimentasi, dan eksplorasi (Knisley, 2003: 5). Kegiatan eksplorasi dapat mendorong siswa membangun pemahaman melalui berbagai pertanyaan atau pengamatan. Kegiatan eksperimentation akan mengakibatkan siswa memiliki pengalaman belajar yang terhubung langsung dengan pengalaman fisik (Muijs, 2010: 861). Oleh karena itu, tahap integration dalam penelitian ini berbentuk kegiatan "Ayo Praktik" yang memberikan kesempatan kepada siswa untuk melakukan kegiatan visualisasi, eksperimentasi, dan eksplorasi.

c. Analysis (analisis)

Tahap analysis merupakan tahapan siswa mulai mengkaitkan konsep baru dengan konsep yang telah dimiliki kemudian menjadikan konsep baru tersebut menjadi bagian dari dasar pengetahuan yang telah ada (Knisley, 2003: 3). Tahap ini juga dipandang sebagai pembelajaran terstruktur yang memfasilitasi siswa dalam menganalisis masalah dan berbagai solusi penyelesaian untuk masalah tersebut (Northrup, 2007: 65). Meskipun siswa sudah bisa mengkaitkan konsep namun siswa belum memiliki informasi yang 
dibutuhkan untuk membentuk karakter tunggal (kesimpulan) dari suatu konsep (Knisley, 2003: 3). Hal ini karena tahap analysis masih sebatas pada aktivitas mendalami materi sehingga siswa siap untuk mempertimbangkan konsep baru secara bebas dengan ide-ide lain yang berkaitan dengan konsep tersebut (Knisley, 2003: 6).

Pada tahap analysis, siswa memiliki keingintahuan tentang sejarah suatu konsep, teknik penggunaan, dan penjelasan dari konteks yang berbeda. Rasa ingin tahu siswa berperan sebagai motivasi untuk melakukan eksplorasi guna mendapatkan pengetahuan yang baru (Litman dan Spielberger, 2003: 75). Rasa ingin tahu tersebut juga menjadi pendorong siswa untuk membuat hubungan baru antara ide-ide, persepsi siswa, konsep, dan representasi konsep matematika yang dipelajari (Zuss, 2012: 117). Oleh karena itu, tahap analysis dalam penelitian ini berbentuk kegiatan "Ayo Mendalami" yang memberikan kesempatan kepada siswa untuk mendalami materi.

d. Synthesis (kesimpulan)

Tahap synthesis merupakan tahapan siswa dapat menyusun konsep baru menjadi identitas tunggal dan menjadi alat untuk mengembangkan strategi serta alegori selanjutnya (Knisley, 2003: 3). Pada tahap ini siswa mengkombinasikan fakta, konsep, dan proses pembelajaran menjadi pengetahuan baru (Orlich, dkk, 2010: 363). Pengetahuan baru tersebut dikomunikasikan secara tunggal menjadi pemahaman yang menjelaskan pola atau struktur suatu konsep berupa kesimpulan (Butcher, dkk, 2006: 47). Oleh karena itu, tahap synthesis dalam penelitian ini berbentuk kegiatan "Kesimpulan dan Latihan Soal" yang memberikan siswa kesempatan untuk merumuskan kesimpulan tentang materi yang telah dipelajari dan mengaplikasikan pengetahuan yang diperoleh untuk menyelesaikan masalah.

Dalam keempat tahap belajar Knisley, guru berperan lebih aktif pada tahapan allegorization dan analysis sedangkan pada tahapan integration dan synthesis guru berperan lebih pasif (Knisley, 2003: 7). Jika dimaknai menurut siswanya maka tahapan allegorization dan analysis siswa berperan pasif sedangkan pada tahapan integration dan synthesis siswa berperan lebih aktif. Menurut Knisley (2003: 7), peran guru untuk setiap tahapan yaitu: (a) Allegorization: Guru sebagai pencerita (storyteller), (b) Integration: Guru sebagai pemandu (guide) dan motivator, (c) Analysis: Guru sebagai sumber informasi (source of information), dan (d) Synthesis: Guru sebagai seorang pelatih (coach)

\section{Perangkat Pembelajaran}

Menurut Trianto (2009: 201), perangkat pembelajaran merupakan perangkat dalam proses pembelajaran. Dalam penelitian ini, perangkat pembelajaran yang dikembangkan yaitu Rencana Pelaksanaan Pembelajaran (RPP) dan Lembar Kerja Siswa (LKS) Geometri Kelas VII SMP dengan kualitas kelayakan perangkat diukur berdasarkan aspek berikut.

a. Kevalidan

Menurut Allen dan Yen (1979: 95), kevalidan dilihat dari validitas isi maupun konstruk. Dalam penelitian ini, validitas yang digunakan adalah validitas isi menurut ahli media, ahli materi, dan guru matematika. Validitas isi dibangun melalui analisis rasional dari isi yang didasarkan pada penilaian individual ahli (Allen dan Yen, 1979: 95).

b. Kepraktisan

Menurut Nieveen (1999: 127), guru dan siswa merupakan subjek penilai kepraktisan perangkat pembelajaran. Dalam penelitian ini, perangkat pembelajaran dikatakan praktis jika guru mudah dalam memahami dan menggunakan RPP dan LKS serta jika siswa mudah dalam memahami dan menggunakan LKS dalam pembelajaran.

c. Keefektifan

Perangkat pembelajaran dikatakan memenuhi kriteria keefektifan jika penggunaan perangkat pembelajaran dapat memberikan hasil sesuai harapan karena adanya apresiasi dari siswa dan pembelajaran yang diharapkan dapat terlaksana dengan baik (Nieveen, 1999: 127). Dalam penelitian ini, keefektifan perangkat pembelajaran ditinjau dari 2 hal 
Heru Tri Novi Rizki, Ariyadi Wijaya, \& Diena Frentika: Pengembangan Perangkat Pembelajaran dengan Pendekatan Knisley Berorientasi pada Level Berpikir Van Hiele dan Kemampuan Penalaran Adaptif

yaitu ketercapaian level berpikir Van Hiele dan kemampuan penalaran adaptif siswa.

\section{Metode Penelitian}

Adapun metode penelitian yang digunakan dalam penelitian ini adalah sebagai berikut.

\section{Jenis Penelitian}

Penelitian ini merupakan penelitian pengembangan $(R \& D)$ dengan model ADDIE. Penelitian ini bertujuan untuk menghasilkan perangkat pembelajaran (RPP dan LKS) pada materi Geometri dengan MPMK yang berorientasi pada LBVH dan KPA siswa kelas VII.

\section{Prosedur Pengembangan}

Prosedur pengembangan dalam penelitian ini adalah sebagai berikut: (a) Analisis (analysis): melakukan analisis kebutuhan, materi, dan karakter siswa, (b) Perancangan (design): merancang RPP dan LKS serta menysusun instrumen penelitian, (c) Pengembangan (development): melakukan pengembangan rencana, validasi ahli, dan revisi berdasarkan masukan ahli, (d) Implementasi (implementation): melakukan uji keterbacaan pada beberapa siswa kelas VIII, revisi jika diperlukan, kemudian uji coba produk dalam pembelajaran kelas VII, dan (e) Evaluasi (evaluation): melakukan analisis kepraktisan dan keefektifan kemudian menyusun laporan hasil pengembangan perangkat pembelajaran.

\section{Waktu dan Tempat Uji Coba Produk}

Uji coba perangkat pembelajaran dilakukan pada 34 siswa SMP Negeri 7 Mataram kelas VII M tahun ajaran 2016/2017.

\section{Data, Instrumen dan Teknik Pengumpulan Data}

Data penelitian yang dikumpulkan adalah data kevalidan, kepraktisan, dan keefektifan perangkat pembelajaran dengan rekapitulasi teknik dan instrumen sebagai berikut.

\section{Tabel 2. Rekapitulasi Teknik dan Instrumen Pengumpulan Data}

\begin{tabular}{cclcc}
\hline Teknik & Aspek & \multicolumn{1}{c}{ Jenis Instrumen } & Subjek & Hasil \\
\hline $\begin{array}{c}\text { Non } \\
\text { Tes }\end{array}$ & Kevalidan & Lembar validasi RPP & $\begin{array}{c}\text { Dosen dan } \\
\text { guru }\end{array}$ & Skor validasi \\
& & $\begin{array}{l}\text { Lembar validasi LKS } \\
\text { Lembar validasi tes LBVH }\end{array}$ & \\
& & Lembar validasi instrumen tes KPA & & \\
& & Siswa & Skor \\
& \multirow{2}{*}{ Kepraktisan } & Lembar keterbacaan LKS & keterbacaan \\
& & pembelajaran & Observer & Persentase \\
& & Angket respon guru & (peliti) & keterlaksanaan \\
& & Angket respon siswa & Suru & Skor \\
Tes & Keefektifan & Instrumen tes LBVH & Siswa & kepraktisan \\
& & Instrumen KPA & & Skor tes \\
\hline
\end{tabular}

Instrumen tes LBVH mengacu pada instrumen tes yang dikembangkan oleh Usiskin (1982) yang terdiri 25 item soal dengan masing-masing LBVH diukur menggunakan 5 item soal pilihan ganda. Adapun instrumen tes KPA terdiri dari 5 soal uraian dengan setiap soal merepresentasikan satu indikator yaitu a) mengajukan konjektur, b) menentukan pola dari suatu kejadian, c) memeriksa kebenaran suatu prosedur atau pernyataan matematika, d) menarik kesimpulan secara logis, e) menjelaskan alasan secara logis.

Lembar kevalidan dan kepraktisan perangkat pembelajaran disusun menggunakan skala Likert berbentuk checklist terdiri dari 5 penilaian. Lembar kevalidan RPP memiliki 28 item 
pernyataan dengan 7 indikator penilaian yaitu 1) identitas RPP, 2) indikator pencapaian kompetensi, 3) tujuan pembelajaran, 4) materi pembelajaran, 5) kegiatan pembelajaran, 6) sumber belajar, dan 7) penilaian. Lembar kevalidan LKS memiliki 45 item pernyataan yang terdiri dari 4 komponen penilaian yaitu 1) kelayakan isi, 2) kebahasaan, 3) penyajian, dan 4) kegrafikan. Angket respon guru memiliki 13 item pernyataan yang terdiri dari 3 komponen penilaian yaitu 1) format LKS, 2) Materi/Isi, dan 3) Bahasa. Angket respon siswa memiliki 12 item pernyataan yang terdiri dari 3 komponen penilaian yaitu 1) bahasa, 2) tampilan, dan 3) kemudahan penggunaan.

Lembar kevalidan instrumen pengumpulan data disusun menggunakan skala Likert berbentuk checklist terdiri dari 2 penilaian bertingkat yaitu valid dan tidak valid. Lembar kevalidan instrumen pengumpulan data memiliki 7 item pernyataan yang terdiri dari 3 aspek penilaian yaitu 1) soal, 2) kebahasaan, dan 3) kunci jawaban dan pedoman penilaian. Adapun lembar observasi keterlaksanaan pembelajaran menggunakan skala Guttman dengan pilihan jawaban ya dan tidak untuk 36 item pernyataan dengan 3 aspek pengamatan yaitu pendahuluan, inti, dan penutup.

\section{Validitas dan Reliabilitas Instrumen}

Berdasarkan penilaian validator, instrumen tes LBVH dan KPA terkategori valid. Adapun estimasi reliabilitas instrumen tes LBVH adalah 0,711 dan KPA adalah 0,852.

\section{Teknik Analisis Data}

Analisis data dalam penelitian ini menggunakan analisis deskriptif dengan konversi skor rerata sebagaimana penjelasan Azwar (2015: 163) dalam bukunya.

a. Analisis Kevalidan dan Kepraktisan

Hasil penilaian kevalidan dan kepraktisan perangkat pembelajaran selanjutnya dikonversi menggunakan skor 1-5 dengan kriteria penilaian hasil disajikan dalam Tabel 3 berikut.

Tabel 3. Kriteria Penilaian Kevalidan dan Kepraktisan Perangkat Pembelajaran

\begin{tabular}{ccc}
\hline \multirow{2}{*}{ Interval Skor } & \multicolumn{2}{c}{ Kriteria Penilaian } \\
\cline { 2 - 3 } & \multicolumn{1}{c}{ Kevalidan } & Kepraktisan \\
\hline $4<X$ & Sangat Baik & Sangat Praktis \\
$2,33<X \leq 4$ & Baik & Praktis \\
$2<7<X \leq 3,33$ & Cukup Baik & Cukup Praktis \\
$2<X \leq 2,67$ & Kurang Baik & Kurang Praktis \\
$X \leq 2$ & Tidak Baik & Tidak Praktis \\
\hline
\end{tabular}

Perangkat pembelajaran dikatakan valid maupun praktis jika memenuhi klasifikasi "Baik" atau rerata skor lebih besar dari 3,33 $(X>3,33)$. Adapun hasil lembar observasi keterlaksanaan pembelajaran dikonversi menggunakan skor 0 dan 1 dengan kriteria berikut.

Tabel 4. Kriteria Kepraktisan Keterlaksanaan Pembelajaran

\begin{tabular}{cc}
\hline Persentase Keterlaksanaan & Kriteria \\
\hline $75<X \leq 100$ & Sangat Praktis \\
$58<X \leq 75$ & Praktis \\
$42<X \leq 58$ & Cukup Praktis \\
$25<X \leq 42$ & Kurang Praktis \\
$0<X \leq 25$ & Tidak Praktis \\
\hline
\end{tabular}

Perangkat pembelajaran dikatakan praktis jika persentase keterlaksanaan proses pembelajaran memenuhi klasifikasi "Praktis" atau $X>75 \%$. 
Heru Tri Novi Rizki, Ariyadi Wijaya, \& Diena Frentika: Pengembangan Perangkat Pembelajaran dengan Pendekatan Knisley Berorientasi pada Level Berpikir Van Hiele dan Kemampuan Penalaran Adaptif

b. Analisis Keefektifan

1) Analisis Hasil Tes LBVH

Siswa SMP umumnya mencapai LBVH pada tahap analisis (Usiskin, 1982; Ural, 2016) sehingga dalam penelitian ini dinyatakan siswa tuntas jika berhasil mencapai level analisis. Menurut Depdiknas (2008b: 4), kriteria keberhasilan pembelajaran adalah jika keberhasilan siswa menyelesaikan serangkaian mencapai tingkat keberhasilan rata-rata kelas $60 \%$. Oleh karena itu, perangkat pembelajaran dikatakan efektif jika persentase minimal siswa yang mencapai level analisis secara klasikal mencapai $60 \%$ dari keseluruhan siswa.

2) Analisis Hasil Tes KPA

Skor tes KPA berada pada rentang 0-16 dengan kriteria sebagai berikut.

Tabel 5. Kriteria Hasil Tes Kemampuan Penalaran Adaptif

\begin{tabular}{cc} 
Interval Rerata Skor & Kriteria \\
\hline $12<X$ & Sangat Tinggi \\
$9<X \leq 12$ & Tinggi \\
$7<X \leq 9$ & Sedang \\
$4<X \leq 7$ & Rendah \\
$X \leq 4$ & Sangat Rendah
\end{tabular}

Siswa dinyatakan tuntas mengikuti pembelajaran ditinjau dari nilai tes KPA jika siswa berhasil mencapai kriteria ketuntasan minimal (KKM) yang ditentukan oleh pihak sekolah yaitu sebesar 75. Adapun perangkat pembelajaran dikatakan efektif jika persentase siswa yang memenuhi ketuntasan klasikal pada tes KPA mencapai $60 \%$ dari keseluruhan siswa.

\section{Hasil Penelitian dan Pembahasan}

Adapun hasil penelitian dan pembahasan dalam penelitian ini adalah sebagai berikut.

\section{Hasil penelitian}

Sebagaimana prosedur pengembangan ADDIE, deskripsi pengembangan produk awal dapat dijelaskan melalui tiga tahapan awal pengembangan sebagai berikut.

a. Analisis (analysis)

Berdasarkan analisis kebutuhan diketahui bahwa perangkat pembelajaran yang mendukung penguasaan kemampuan berpikir geometri masih perlu dikembangkan menurut hasil observasi dan wawancara dengan guru kelas 7 di SMP N 7 Mataram serta belum tersedianya ruang bagi siswa untuk terlibat aktif melalui proses menemukan, mengeksplorasi, maupun berdiskusi karena LKS yang digunakan memberikan rangkuman materi secara langsung. Berdasarkan analisis materi, dipilihlah materi bangun datar segitiga dan segiempa untuk dikembangkan dalam penelitian ini. Berdasarkan analisis karakter diketahui bahwa kecenderungan siswa belajar dari tahap kongkret menuju abstrak sesuai dengan tahapan belajar pada model pembelajaran matematika Knisley.

b. Perencanaan (design)

Pada tahap ini dilakukan perancangan perangkat pembelajaran dengan target capaian yang diperoleh yaitu prototype untuk RPP dan LKS serta instrumen penelitian yang terdiri dari instrumen untuk mengukur aspek kevalidan, kepraktisan, dan keefektifan. Selain itu dirancang pula bagian-bagian yang berorientasi untuk memfasilitasi LBVH dan KPA.

c. Pengembangan (development)

Pada tahap ini, produk awal untuk RPP dan LKS beserta dengan instrumen penelitian telah selesai dikembangkan sesuai dengan desain yang ditentukan. Produk awal tersebut selanjutnya divalidasi oleh para ahli untuk mengetahui kevalidan perangkat pembelajaran, instrumen tes LBVH dan instrumen tes KPA. Pada tahap ini dilakukan pula revisi 
berdasarkan hasil penilaian ahli jika diperlukan. LKS yang sudah direvisi selanjutnya diujicoba keterbacaan pada siswa kelas VIII. Setelah LKS dinyatakan memiliki tingkat keterbacaan yang baik dilakukan uji coba produk pada siswa kelas VII dalam pembelajaran di kelas.

Adapun hasil uji coba perangkat pembelajaran dalam penelitian ini adalah sebagai berikut

a. Kevalidan Perangkat Pembelajaran

Berdasarkan penilaian ahli, perangkat pembelajaran dinyatakan valid dan layak. Rerata skor validasi RPP adalah 4,18 dengan kriteria penilaian sangat baik. Rerata skor validasi LKS adalah 4,23 dengan kriteria sangat baik. Berikut adalah penilaian kevalidan RPP setiap aspek.

Tabel 6. Hasil Analisis Kevalidan RPP Setiap Aspek

\begin{tabular}{clcc}
\hline No & \multicolumn{1}{c}{ Aspek yang Dinilai } & Rerata Skor & Kriteria \\
\hline 1 & Identitas RPP & 4,667 & Sangat Baik \\
2 & Indikator Pencapaian Kompetensi & 4,333 & Sangat Baik \\
3 & Tujuan Pembelajaran & 4,222 & Sangat Baik \\
4 & Materi Pembelajaran & 4 & Baik \\
5 & Kegiatan Pembelajaran & 4,074 & Sangat Baik \\
6 & Sumber Belajar & 4,333 & Sangat Baik \\
7 & Penilaian & 4 & Baik \\
\hline
\end{tabular}

Adapun penilaian kevalidan LKS setiap aspek disajikan oleh Tabel 7 berikut.

Tabel 7. Hasil Analisis Kevalidan LKS Setiap Aspek

\begin{tabular}{|c|c|c|c|}
\hline No & Aspek yang Dinilai & Rerata Skor & Kriteria \\
\hline 1 & Kelayakan isi & 4,183 & Sangat Baik \\
\hline 2 & Kebahasaan & 4,333 & Sangat Baik \\
\hline 3 & Penyajian & 4,167 & Sangat Baik \\
\hline 4 & Kegrafikan & 4,262 & Sangat Baik \\
\hline
\end{tabular}

Tabel 6 dan 7 di atas menunjukkan bahwa setiap aspek penilaian kevalidan perangkat pembelajaran yang dikembangkan memenuhi aspek kevalidan menurut penilaian para ahli.

b. Kepraktisan Perangkat Pembelajaran

Adapun hasil penilaian kepraktisan menggunakan angket respon guru dan siswa dijelaskan pada Tabel 8 berikut.

Tabel 8. Hasil Analisis Kepraktisan Perangkat Pembelajaran

\begin{tabular}{cccc}
\hline Penilaian & Aspek yang Dinilai & Rerata Skor & Kriteria \\
\hline Guru & Kepraktisan RPP & 5 & Sangat Baik \\
& Kepraktisan LKS & 5 & Sangat Baik \\
Siswa & Kepraktisan LKS & 4,538 & Sangat Baik \\
\hline
\end{tabular}

Berdasarkan Tabel 8 diketahui bahwa perangkat pembelajaran yang dikembangkan memenuhi aspek kepraktisan berdasarkan angket respon guru dan siswa dengan kriteria sangat praktis. Adapun rekapitulasi keterlaksanaan pembelajaran adalah sebagai berikut. 
Heru Tri Novi Rizki, Ariyadi Wijaya, \& Diena Frentika: Pengembangan Perangkat Pembelajaran dengan Pendekatan Knisley Berorientasi pada Level Berpikir Van Hiele dan Kemampuan Penalaran Adaptif

Tabel 9. Hasil Observasi Keterlaksanaan Proses Pembelajaran

\begin{tabular}{ccccc}
\hline \multirow{2}{*}{$\begin{array}{c}\text { Pertemuan } \\
\text { ke- }\end{array}$} & \multicolumn{2}{c}{ Keterlaksanaan Aktivitas Guru } & \multicolumn{2}{c}{ Keterlaksanaan Aktivitas Siswa } \\
\cline { 2 - 5 } & Persentase & Kategori & Persentase & Kategori \\
\hline 1 & $77,8 \%$ & Sangat praktis & $75 \%$ & Praktis \\
2 & $91,7 \%$ & Sangat praktis & $86,1 \%$ & Sangat praktis \\
3 & $94,4 \%$ & Sangat praktis & $94,4 \%$ & Sangat praktis \\
4 & $94,4 \%$ & Sangat praktis & $94,4 \%$ & Sangat praktis \\
5 & $91,7 \%$ & Sangat praktis & $91,7 \%$ & Sangat praktis \\
\hline Rerata & $\mathbf{9 0} \%$ & Sangat praktis & $\mathbf{8 8 , 3 2 \%}$ & Sangat praktis \\
\hline
\end{tabular}

Berdasarkan Tabel 9, presentase keterlaksanaan pembelajaran $>75 \%$ sehingga memenuhi aspek kepraktisan dengan kategori sangat praktis menurut keterlaksanaan pembelajaran.

c. Keefektifan Perangkat Pembelajaran

1). Level Berpikir Van Hiele

Dalam penelitian ini, perangkat pembelajaran dikatakan efektif jika persentase minimal siswa yang mencapai level berpikir analisis secara klasikal adalah $60 \%$ dari keseluruhan siswa. Adapun rekapitulasi hasil tes LBVH sebagai berikut.

Tabel 10. Rekapitulasi Pencapaian Level Berpikir Van Hiele

\begin{tabular}{lcccc}
\hline \multicolumn{1}{c}{ Level Berpikir } & \multicolumn{2}{c}{ Data Pretes } & \multicolumn{2}{c}{ Data Postes } \\
\cline { 2 - 5 } \multicolumn{1}{c}{ Van Hiele } & Frekuensi & Persentase & Frekuensi & Persentase \\
\hline Pre-visualisasi & 5 & $15 \%$ & 1 & $3 \%$ \\
Visualisasi & 15 & $44 \%$ & 7 & $21 \%$ \\
Analisis & 14 & $41 \%$ & 23 & $68 \%$ \\
Order & 0 & $0 \%$ & 3 & $9 \%$ \\
Deduktif dan Rigor & 0 & $0 \%$ & 0 & $0 \%$ \\
\hline Total & $\mathbf{3 4}$ & $\mathbf{1 0 0} \%$ & $\mathbf{3 4}$ & $\mathbf{1 0 0} \%$ \\
\hline
\end{tabular}

Berdasarkan Tabel 10, terjadi peningkatan jumlah siswa yang mencapai level analisis setelah menggunakan perangkat pembelajaran yang dikembangkan. Pada data pretes, baru $41 \%$ siswa mencapai level berpikir analisis dan belum ada siswa yang mencapai level berpikir order. Setelah memperoleh pembelajaran matematika Knisley, persentase siswa pada tahap berpikir analisis menjadi $77 \%$ dengan rincian $68 \%$ siswa mencapai level berpikir analisis dan 9\% siswa mencapai level order. Dengan demikian persentase siswa yang ada pada level analisis lebih besar dari kriteria yang ditentukan (60\%) sehingga perangkat pembelajaran memenuhi aspek keefektifan berdasarkan LBVH.

2). Kemampuan Penalaran Adaptif

Dalam penelitian ini, perangkat pembelajaran dikatakan efektif jika persentase siswa yang memenuhi ketuntasan $(\mathrm{KKM}=75)$ secara klasikal pada tes KPA mencapai $60 \%$ dari keseluruhan siswa. Adapun rekapitulasi hasil tes KPA adalah sebagai berikut.

Tabel 11. Rekapitulasi Hasil Tes Kemampuan Penalaran Adaptif

\begin{tabular}{ccccc}
\hline \multirow{2}{*}{ No Soal } & \multicolumn{2}{c}{ Data Pretes } & \multicolumn{2}{c}{ Data Postes } \\
\cline { 2 - 5 } & Rerata & Nilai & Rerata & Nilai \\
\hline 1 & 0,18 & 5,88 & 1,85 & 61,8 \\
2 & 0 & 0 & 2,71 & 90,6 \\
3 & 0 & 0 & 2,94 & 73,5 \\
4 & 0 & 0 & 1,62 & 53,9 \\
5 & 0,06 & 1,96 & 1,35 & 45,1 \\
\hline
\end{tabular}


Berdasarkan Tabel 11, diketahui bahwa KPA siswa mengalami peningkatan yang signifikan setelah memperoleh pembelajaran matematika Knisley menggunakan perangkat yang dikembangkan. Pada data pretes, kelima indikator KPA belum dikuasai siswa. Namun pada data pretes, siswa mampu mendapatkan nilai 61,8 untuk kemampuan mengajukan konjektur, 90,6 untuk kemampuan menentukan pola dari suatu kejadian, 73,5 untuk kemampuan memeriksa kebenaran suatu prosedur atau pernyataan matematika, 53,9 untuk kemampuan menarik kesimpulan secara logis, dan 45,1 untuk kemampuan menjelaskan alasan secara logis. Adapun rekapitulasi skor KPA siswa sebagai berikut.

Tabel 12. Rekapitulasi Skor Kemampuan Penalaran Adaptif

\begin{tabular}{lccccc}
\hline & Nilai max & Nilai min & Rerata kelas & Rerata skor & Kategori \\
\hline Pretes & 23,5 & 0 & 0 & 0,235 & Sangat rendah \\
Postes & 93,8 & 0 & 65,4 & 10,47 & Tinggi \\
\hline
\end{tabular}

Berdasarkan Tabel 12, perangkat pembelajaran yang dikembangkan memiliki rerata kelas sebesar 65,4 dan rerata skor sebesar 10,47 dengan kategori tinggi. Adapun rekapitulasi ketuntasan KPA adalah sebagai berikut.

Tabel 13. Rekapitulasi Ketuntasan Kemampuan Penalaran Adaptif

\begin{tabular}{lcccc}
\hline & \multicolumn{2}{c}{ Pretes } & \multicolumn{2}{c}{ Postes } \\
\cline { 2 - 5 } & Banyak siswa & Presentase & Banyak siswa & Presentase \\
\hline Tuntas & 0 & $0 \%$ & 22 & $64,71 \%$ \\
Belum tuntas & 34 & $100 \%$ & 12 & $35,29 \%$ \\
Total & 34 & $100 \%$ & 34 & $100 \%$ \\
\hline
\end{tabular}

Berdasarkan Tabel 13, persentase siswa yang tuntas saat pretes adalah $0 \%$ dan naik menjadi $64,71 \%$ saat postes. Dengan demikian capaian persentase ketuntasan lebih besar dari kriteria yang ditentukan $(60 \%)$ sehingga perangkat pembelajaran memenuhi aspek keefektifan berdasarkan KPA siswa.

\section{Pembahasan}

Hasil penelitian ini menunjukkan bahwa perangkat pembelajaran dengan pendekatan MPMK yang berorientasi pada LBVH dan KPA siswa layak digunakan karena memenuhi aspek kevalidan, kepraktisan, dan keefektifan. Perangkat pembelajaran dinyatakan valid oleh ahli karena dalam penyusunannya didasarkan pada aturan dan teori yang relevan. RPP yang disusun memenuhi kelengkapan komponen standar sebagaimana terangkum dalam Permendikbud No 22 Tahun 2016. LKS yang dikembangkan juga memenuhi komponen standar sebagaimana termuat dalam Depdiknas (2008a) serta mengacu pada teori MPMK yang memuat 4 tahapan belajar yaitu allegorization, integrator, analysis, dan synthesis. Keempat tahapan tersebut diwujudkan dalam aktivitas belajar yang dirancang untuk memfasilitasi proses belajar aktif siswa sehingga menstimulus terjadinya peningkatan LBVH dan KPA.

Tahap allegorization yang dimaknai sebagai tahapan pembelajaran untuk mengkaitkan pengetahuan yang dimiliki diwujudkan dalam aktivitas "Ayo Mengingat". Aktivitas ini sejalan dengan pernyataan Knisley (2003: 3) bahwa "Allegorization is a new concept is described figuratively in a familiar context in terms of known concepts". Tahap integration diwujudkan dalam kegiatan "Ayo Praktik" karena tahap integration dimaknai sebagai tahap belajar siswa untuk melakukan perbandingan, pengukuran, dan eksplorasi dalam membedakan konsep baru dengan konsep-konsep yang telah diketahui (Knisley, 2003: 3). Selain itu, kunci utama untuk sukses dalam tahap ini ada 3 yaitu visualisasi, eksperimentasi, dan eksplorasi (Knisley, 2003: 5). 
Heru Tri Novi Rizki, Ariyadi Wijaya, \& Diena Frentika: Pengembangan Perangkat Pembelajaran dengan Pendekatan Knisley Berorientasi pada Level Berpikir Van Hiele dan Kemampuan Penalaran Adaptif

Dengan demikian "Ayo Mengingat" dan "Ayo Praktik" memiliki kesesuaian dengan tahap belajar allegorization dan integrator yang dikemukakan Knisley.

Tahap ketiga yaitu analisis dimaknai sebagai tahapan siswa mulai mampu mengkaitkan konsep baru dengan konsep yang sudah ada kemudian menjadikan konsep baru itu menjadi bagian dari pengetahuan yang telah ada (Knisley, 2003: 3). Akan tetapi siswa belum memiliki informasi yang dibutuhkan untuk membentuk karakter tunggal (kesimpulan) dari suatu konsep (Knisley, 2003: 3). Hal ini karena tahap analysis masih sebatas pada aktivitas mendalami materi sehingga siswa siap untuk mempertimbangkan konsep baru secara bebas dengan ide-ide lain yang berkaitan dengan konsep tersebut (Knisley, 2003: 6). Oleh karena itulah, tahap analisis diimplementasikan dalam kegiatan "Ayo Mendalami" yang motivasi siswa untuk melakukan analisis mendalam tentang suatu konsep dengan memanfaatkan ide-ide yang berkaitan dengan konsep tersebut.

Tahap keempat yaitu synthesis dijelaskan sebagai tahapan siswa untuk dapat menyusun konsep baru menjadi identitas tunggal dan menjadi alat untuk mengembangkan strategi serta alegori selanjutnya (Knisley, 2003: 3). Pada tahapan ini siswa dilatih untuk mempersiapkan pengetahuan yang nantinya akan digunakan lagi untuk mempelajari konsep baru selanjutnya. Kesiapan siswa tersebut diwujudkan dengan aktivitas "Kesimpulan dan Latihan Soal" yang memberikan ruang pada siswa untuk merumuskan kesimpulan tentang materi yang dipelajari serta mengaplikasikan pengetahuan baru yang telah dipelajarinya untuk menyelesaikan masalah. Hal ini karena pada tahap ini siswa mengkombinasikan fakta, konsep, dan proses pembelajaran menjadi pengetahuan baru (Orlich, dkk, 2010: 363).

Implementasi keempat aktivitas dalam LKS yang dikembangkan selain dirancang sesuai dengan teori MPMK, dirancang pula agar mudah dipahami dan digunakan oleh guru maupun siswa. Kejelasan setiap tahapan pembelajaran menggunakan istilah yang dipahami siswa seperti ayo mengingat, ayo praktik, ayo memahami, serta kesimpulan dan saran, berpeluang untuk meningkatkan kepraktisan penggunaan perangkat pembelajaran karena kemudahan siswa dan guru dalam melaksanakan setiap tahapan proses pembelajarannya. Selain itu adanya pembagian peran guru dan siswa dalam setiap tahapan Knisley juga diduga memberikan dukungan pada tingkat kepraktisan penggunaan perangkat pembelajaran. Kolaborasi aktif-pasif yang jelas antara guru dan siswa menjadikan setiap tahapan pembelajaran menjadi lebih interaktif.

Hasil penelitian juga menunjukkan bahwa implementasi MPMK dengan menggunakan perangkat pembelajaran yang dikembangkan efektif dalam meningkatkan LBVH dan KPA. Dugaan atas kondisi tersebut adalah karena MPMK sejalan dengan pandangan learning as understanding (Dedy, dkk, 2012: 107) sehingga diindikasi mampu memfasilitasi kemampuan berpikir matematis. Selain itu, peningkatan kemampuan berpikir siswa juga dimungkinkan dapat terjadi karena adanya antusiasme dan pengetahuan awal untuk membentuk kesiapan belajar siswa pada tahap allegorization sebagaimana pernyataan Knisley (2003: 1), "good teaching begins with a genuine concern for students and an enthusiasm for the subject". Adanya antusiasme tersebut menjadikan siswa lebih termotivasi untuk belajar dan memahami konsep baru. Dengan motivasi tersebut siswa menjadi lebih mudah mencapai tujuan pembelajaran (Lucas, dkk, 2010: 3) karena motivational context adalah kunci utama pembelajaran yang baik (Butcher, dkk, 2006: 102).

Knisley (2003: 1) juga mengungkapkan dengan model pembelajaran ini maka guru dapat mengatasi masalah pendidikan seperti peran keefektifan guru dan ketepatan penggunaan teknologi. Hal ini tidak hanya terdapat pada tahap allegorization, namun pada setiap tahapan yang sesuai dengan kebutuhan untuk memfasilitasi kemampuan berpikir siswa. Pada tahap integrator, siswa melakukan eksplorasi konsep bangun datar segitiga dan segiempat sehingga menunjang peningkatan kemampuan berpikir. Melalui eksplorasi tersebut, siswa menemukan konsep dan tidak hanya hafalan sehingga kemampuan bernalar dan LBVH dapat terfasilitasi.

Tahapan analisis dirancang untuk memfasilitasi siswa dalam menganalisis masalah dan berbagai solusi penyelesaian (Northrup, 2007: 65). Pada tahap ini siswa memiliki keingintahuan yang memacu untuk mengeksplorasi pengetahuan dan meningkatkan ketertarikan terhadap suatu 
objek (Kashdan, dkk, 2004: 291). Rasa ingin tahu siswa menjadi motivasi untuk menemukan pengetahuan yang baru (Litman dan Spielberger, 2003: 75) dan menjadi pendorong untuk membuat hubungan baru antara ide-ide, persepsi siswa, konsep, dan representasi konsep matematika yang dipelajari (Zuss, 2012: 117). Analisis tentang pengetahuan baru menjadikan siswa mengkombinasikan fakta, konsep, dan proses pembelajaran menjadi pengetahuan baru (Orlich, dkk, 2010: 363) dalam tahap synthesis melalui aktivitas merumuskan kesimpulan dan latihan soal untuk mengaplikasikan pengetahuan yang diperoleh. Oleh karena itulah, hubungan cyclic pada keempat tahap MPMK dapat mendukung peningkatan LBVH dan KPA.

\section{E. Simpulan}

Berdasarkan penjelasan di atas, perangkat pembelajaran dengan pendekatan Knisley yang berorientasi pada level berpikir Van Hiele dan kemampuan penalaran adaptif layak digunakan karena memenuhi kriteria berikut 1) sangat valid menurut ahli dengan skor rerata 4,179 untuk RPP dan 4,230 untuk LKS, 2) sangat praktis menurut penilaian guru dengan skor rerata 5 untuk LKS dan RPP serta sangat praktis menurut penilaian siswa dengan skor rerata 4,538 untuk LKS, dan 3) sangat efektif berdasarkan level berpikir Van Hiele dengan banyaknya siswa pada level analisis mencapai $77 \%$ dan berdasarkan kemampuan penalaran adaptif dengan ketercapaian persentase ketuntasan $64,71 \%$, rerata kelas 65,4 dan rerata skor 10,47 dengan kategori tinggi.

\section{DAFTAR PUSTAKA}

Abdussakir. (2009). Pembelajaran geometri sesuai teori Van Hiele. Madrasah, 11(1), 1-13.

Abu, M. S., \& Abidin, Z. Z. (2013). Improving the levels of geometric thinking of secondary school students using geometry learning video based on Van Hiele theory. International Journal of Evaluation and Research in Education (IJERE), 2(1), 16-22.

Aditya, Y., Mulyana, E. \& Kustiawan, C. (2012). Implementasi model pembelajaran matematika knisley dalam upaya meningkatkan kemampuan penalaran matematis siswa SMA. Jurnal Pengajaran MIPA, 17(1), 8-16.

Alex, J. K., \& Mammen, K. J. (2012). A survey of South African grade 10 learners' geometric thinking levels in terms of the Van Hiele theory. Anthropologist, 14(2), 123-129.

Allen, M.J. \& Yen, W.M. (1979). Introduction to measurement theory. Monterey, CA: Brooks/Cole Publishing Company.

Ardiansyah, Heru. (2012). Penerapan Pembelajaran Menggunakan Pemberian Tugas Bentuk Superiten pada Metode Diskusi terhadap Peningkatan Kemampuan Penalaran Adaptif Matematis Siswa SMA. Skripsi Sarjana S1 pada UPI Bandung. Tidak Diterbitkan.

Azwar, S. (2015). Tes prestasi: Fungsi dan pengembangan pengukuran prestasi belajar. Yogyakarta: Pustaka Pelajar Offset.

Bal, A. P. (2011). Geometry thinking levels and attitudes of elementary teacher candidates. Inonu University Journal of the Faculty of Education, 12(3), 97-115.

BSNP. (2016). Panduan pemanfaatan hasil UN tahun pelajaran 2015/2016 untuk perbaikan mutu pendidikan. Jakarta: Kementerian Pendidikan Nasional Badan Penelitian dan Pengembangan Pendidikan.

Buhaerah. (2011). Pembelajaran berbasis masalah untuk meningkatkan kemampuan penalaran matematis siswa SMP. Gamatika, 2(1), 52-61.

Burger, W. F., \& Shaughnessy, J. M. (1986). Characterizing the van Hiele levels of development in geometry. Journal for research in mathematics education, 17(1), 31-48.

Butcher, C., Davies, C., \& Highton, M. (2006). Designing learning: From module outline to effective learning. New York, NY: Routledge.

Crowley, M.L. (1987). The Van Hiele model of the geometric thought. Dalam Linquist, M.M. (eds) Learning and Teaching Geometry, K-12. Virginia: The NCTM, Inc 
Heru Tri Novi Rizki, Ariyadi Wijaya, \& Diena Frentika: Pengembangan Perangkat Pembelajaran dengan Pendekatan Knisley Berorientasi pada Level Berpikir Van Hiele dan Kemampuan Penalaran Adaptif

Dedy, E., Mulyana, E., \& Sudihartinih, E. (2012). Pengembangan bahan ajar kalkulus vektor berdasarkan model pembelajaran matematika knisley sebagai upaya meningkatkan kompetensi matematika mahasiswa. Pythagoras, 7(1), 101-112.

Depdiknas. (2008a). Panduan pengembangan bahan ajar. Jakarta: Depdiknas.

Depdiknas. (2008b). Kriteria dan indikator keberhasilan pembelajaran. Jakarta: Depdiknas.

Donovan, M.S \& Bransford, J.D. (2005). How students learn history, mathematics, and science in the classroom. Washington, D.C.: National Academies Press

Jaya, M.S.M. \& Kumaidi. (2014). Analisis kesalahan dalam menyelesaikan soal UN matematika tahun pelajaran 2012/2013 di Kota Mataram. Jurnal Evaluasi Pendidikan, 2(2), 181189.

Kashdan, T.B., Rose, P., \& Fincham, F.D.(2004). Curiosity and exploration: facilitating positive subjective experiences and personal growth opportunities. Journal of Personality Assesment, 82(3), 291-305.

Kemp, J.E., Morrison, G.R, \& Ross, S.M. (1998). Design effective instruction. New York, NY: Macmilan College Publishing Company.

Kennedy, L.M., Tipps, S., \& Johnson, A. (2008). Guiding children's learning of mathematics. Kendallville, Indiana: Thomson Higher Education.

Kilpatrick, J., Swafford, J., \& Findell, B. (2001). Adding it up: Helping children learn mathematics. Washington, DC: National Academy Press.

Knisley, J. (2003). Four-stage model of mathematical learning.mathematics. Educator, 12(1), 110.

Kolb, D. A. (2015). Experiential learning: Experience as the source of learning and development $\left(2^{\text {ed }}\right)$. Upper Saddle River, New Jersey, NJ: Pearson Education, Inc.

Kurniawati, M. (2012). Upaya meningkatkan level berpikir geometrik van hiele pada siswa smp dengan menggunakan model pembelajaran matematika knisley. Skripsi UPI: Tidak Diterbitkan (Diakses dari repository UPI)

Litman, J.A., \& Spielberger, C.D. (2003). Measuring epistemic curiosity and its deversive and specific components. Journal of Personality Asessment, 80(1), 75-86.

Litbang. (2010). Survei internasional PISA. Tersedia dalam http://litbang.kemdikbud.go.id/index.php/survei-internasional-pisa.

Lucas, R.I, Pulido, D., Miraflores, D., Ignacio, A., Tacay, M., \& Lao, J. (2010). A study on the motivation factors in second language learning among selected freshman students. Philippines ESL Journal, 4, 3-21.

Mayberry, J. (1983). The van Hiele levels of geometric thought in undergraduate preservice teachers. Journal for research in mathematics education, 58-69.

Muijs, D. (2010). Changing classroom learning. Dalam Hargreaves, A., Lieberman, A., Fullan, M., \& Hopkins, D. (2010). Second international handbook of educational change. London, NY: Springer Dordrecht Heidelberg.

Mulyana, E. (2012). Pengaruh model pembelajaran matematika knisley terhadap peningkatan pemahaman dan disposisi matematika siswa sekolah menengah atas program ilmu pengetahuan alam. Artikel Jurnal Pasca UPI, 1-13.

Musa, L. A. D. (2016). Level berpikir geometri menurut teori Van Hiele berdasarkan kemampuan geometri dan perbedaan gender siswa kelas VII SMPN 8 Parepare. AlKhwarizmi: Jurnal Pendidikan Matematika dan Ilmu Pengetahuan Alam, 4(2), 103-116.

Nieveen, N. (1999). Propotyping to research product quality: Design approach and tool in education an training. Dordrecht, Holland: Kluwer Academic Publisher.

Northrup, P.T. (2007). Learning objects: For instruction design and evaluation. United State: Information Science Publishing (an imprint of IGI Global).

Orlich, D.C., Harder, R.J., Callahan, R.C., Trevisan, M.S., \& Brown, A.H. (2010). Teaching strategies: A guide to effective instruction $\left(9^{\text {th }} \mathrm{ed}\right)$. Wadsworth: Cengage Learning.

Ostler, E. (2011). Teaching adaptive and strategic reasoning through formula derivation: beyond formal semiotics. International Journal Of Mathematics Science Education, 4(2),16-26. 
Permendikbud. (2016). No 22 Tentang Standar Proses Pendidikan Dasar dan Menengah. Jakarta: Pemendikbud.

Permendiknas. (2006). No 22. Tentang Standar Isi untuk Satuan Pendidikan Dasar dan Menengah. Jakarta: Pemendiknas.

Poh \& Leong (2015). Enhancing Van Hiele's level of geometric understanding using Geometer's Sketchpad. 7th ICMI-East Asia Regional Conference on Mathematics Education, Cebu City, Philippines. 501-507.

Rosnawati, R. (2013). Kemampuan Penalaran Matematika Siswa SMP Indonesia pada TIMSS 2011. Prosiding Seminar Nasional Penelitian, Pendidikan dan Penerapan MIPA, Fakultas MIPA, Universitas Negeri Yogyakarta, 18 Mei 2013, (1-6).

Saputri, I., Susanti, E., \& Aisyah, N. (2017). Kemampuan penalaran matematis siswa menggunakan pendekatan metaphorical thinking pada materi perbandingan kelas VIII di SMPN1 Indralaya Utara. Jurnal Elemen, 3(1), 15-24.

Subanindro. (2012). Pengembangan perangkat pembelajraan trigonometri berorientasikan kemampuan penalaran dan komunikasi matematik siswa SMA. Prosiding ISBN: 978979-16353-8-7.

Sugiyarti. (2013). Pengembangan Buku siswa dengan mengacu lima fase belajar model van Hiele pada materi bangun ruang sisi datar kelas VIII SMP laboratorium Universitas Negeri Malang. Jurnal Pendidikan Sains, 1(1), 79-84.

Trianto. (2009). Mendesain model pembelajaran inovatif-progresif: Konsep, landasan, dan implementasinya pada kurikulum tingkat satuan pendidikan (KTSP). Jakarta: Kencana Prenada Media Group.

Ural, A. (2016). Investigating 11 th grade students' van-Hiele level 2 geometrical thinking. Journal of Humanities And Social Science, 21(12), 13-19.

Usiskin. (1982). Van Hiele levels and achievement in secondary school geometry. Lost Angeles, LA: Public Schools Mary Grace Kantowski.

Van de Walle, J.A., Karp, K. S., \& Bay-Williams, J.M. (2010). Elementary and middle school mathematics: Teaching developmentally $\left(7^{\text {th }}\right.$ ed). Boston: Allyn and Bacon.

Watkins, C., Carnell, E., Lodge, C, Wagner, P., \& Whalley, C. (2000). Learning about learning. London: Routledge.

Widjajanti, D.B. (2011). Mengembangkan kecakapan matematis mahasiswa calon guru matematika melalui strategi perkuliahan kolaboratif berbasis masalah. Yogyakarta: Prosiding Semnas UNY.

Yazdani, M.A. (2007). Correlation between students' level of understanding geometry according to the van Hieles' model and students' achievement in plane geometry. Journal of Mathematical Sciences \& Mathematics Education, 2(1), 40-45.

Yin, H.S. (2003). Young children's concept of shape: Van Hiele level geometric thinking. The Mathematics Educator, 7(2), 71-85.

Zhou, N. (2005). Four 'pillars of learning' for the reorientation and reorganization of curriculum: Reflections and discussions. International Bureau of Education-UNESCO.

Zuss, M. (2008). The practice of theorical curiosity. New York: Springer and Bussiness Media. 